\title{
JAMES WILLIAM BROWN
}

James Brown died quite suddenly on September 16, 1958, aged 61, after a short illness of which few of his friends were aware.

He had a remarkable career in cardiology the like of which has not been seen since Mackenzie's day. Born in Gloucester, his youth was spent in the country, where he became deeply versed in everything appertaining to rural life and pastimes, and he never lost his love of the countryside, often surprising his friends in later life by his great store of knowledge of natural history.

During the 1914 War, his Quaker upbringing induced him to join the French Red Cross in which he served for several years. After this he entered the Middlesex Hospital as a student. He had little interest in games, and always impressed his fellow students as a man of ripe wisdom who followed his own bent in the pursuit of knowledge without much regard to his teachers. $\mathrm{He}$ became an expert histologist and later on he demonstrated histology in the physiological department. After qualifying in 1923, he continued to follow the principle that nothing worth knowing can be taught, and instead of seeking an appointment as house physician, he obtained the senior resident post of Casualty Medical Officer in which he had his own out-patient clinic. This was a most unusual proceeding, but Brown was no ordinary man and it would have been difficult to imagine him as a house physician.

In 1924, he joined his father-in-law in general practice in Lincolnshire, first at Cleethorpes and later at Grimsby. He continued in general practice for fourteen years, taking his M.D., London, and M.R.C.P. without difficulty, and being elected, in 1935, to the Association of Physicians, a most unusual distinction. Finding himself handicapped in practice by lack of pathological facilities, he trained himself in laboratory work, making frequent visits to the Middlesex for this purpose, and in due course was appointed Pathologist to the Grimsby Hospital.

He became interested in rheumatic heart clinics for school children and, in 1930, was invited by Muir to join in running a school heart clinic at Hull where rheumatic fever was a notifiable disease. Before long he became physician to school rheumatism and heart clinics at Hull, at Grimsby, and in the Holland and Lindsey divisions of Lincolnshire. It was in this way that his interest in congenital heart disease developed and in the course of time he recorded and indexed almost every case of the kind in the County. Such was his zeal for keeping records that, when war seemed imminent, he took photographic miniatures of all his school clinic notes, including radiographs. He had a wonderful way of handling children who quickly became devoted to him, and he took a personal interest in every child in these clinics. When one of his small patients died, he was always informed at once, and often he was allowed to make a post-mortem examination. As pathologist to the hospital, he.had facilities for preserving and collecting his specimens of congenital heart disease, of which he invariably took photographs himself and often made his own drawings. Many of the figures in his book were drawn by his own hand.

In 1932, he published with Muir a paper on patent ductus arteriosus and this was followed by papers on ventricular septal defect, cyanotic congenital heart disease, congenital aortic stenosis, tricuspid atresia, and coarctation of the aorta with bacterial endocarditis.

In 1937, he wrote with Bedford the section on congenital heart disease in the British Encyclopadia of Medical Practice. By this time he had accumulated a wealth of clinical and pathological material, and he had thoroughly mastered the literature of congenital heart disease, so that the project of writing a book on the subject was encouraged and welcomed by his friends. In 1938, he abandoned general for consulting practice and in 1939 the first edition of his remarkable book Congenital Heart Disease was published. A Spanish edition was published in Buenos Aires in 1948. 


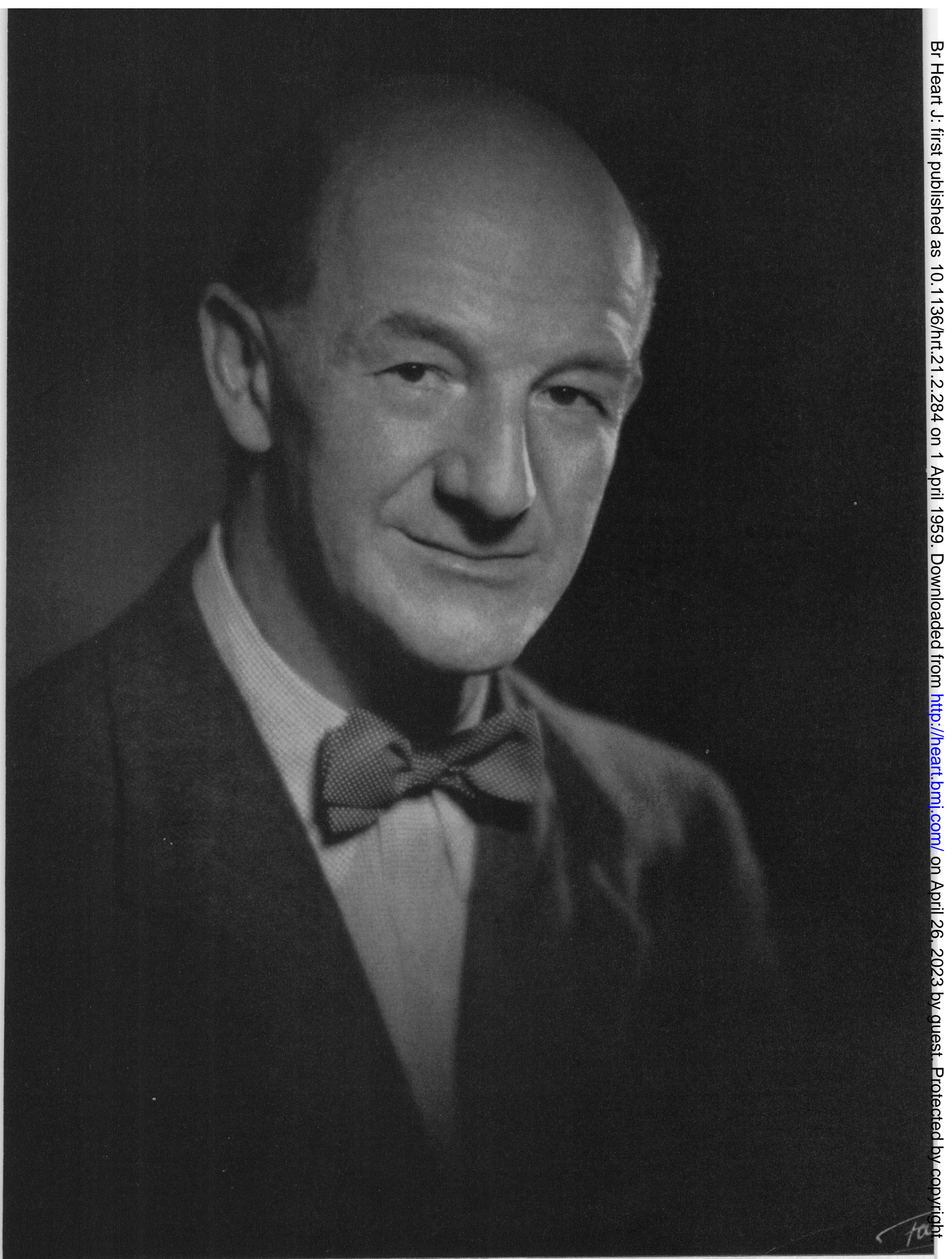


When the time came to prepare a second edition of this book, which was published in 1950 , the rapid advances in our knowledge of congenital heart disease made his task extremely difficult, but he decided to confine it to those aspects with which he was so familiar. Part of a review of the book by Paul Wood is worth quoting: "Erudition and simplicity are harmoniously welded and more than 700 references are incorporated without detracting from its fluency. The author's practical experience of congenital heart disease, both at the bedside and in the post-mortem room is probably unique in this country and forms the basis of this book. It is, indeed, remarkable that a work on this subject could command such respect without paying tribute to modern techniques. But what may be lost by these omissions is made up by a wealth of other material, and it is just these riches which Dr. Brown has so ably presented and which might so easily have been lost that make the book so valuable."

In order to appreciate Brown's achievement one must realize that, in the presurgical era, congenital heart disease was comparatively rare in hospital practice, for parents knew that nothing could be done for these children and often sought to prevent them becoming objects of medical curiosity at hospital. So no one could claim any great clinical experience of congenital heart disease judged by the standards of today, when a cardiologist associated with a cardiac surgical centre may see more cases in a few years than was possible in a lifetime in the past. Brown realized that school clinics provided the opportunity of seeing virtually every case of congenital heart disease of school age and also of following them up, so he travelled all over the county and to Hull to attend these clinics, and this must have deprived him of most of his leisure.

Knowledge of congenital heart disease at this period was largely based on necropsy reports of single cases and on Maude Abbott's invaluable analysis of published records. Apart from this, there were several works published in the previous century, notably those of Farre, Peacock, and Vierordt, the pathological atlas of Théremin's specimens from the Foundling Hospital in St. Petersburg and, of course, the embryological works of Rokitansky, Keith, and Spitzer. All of these were mainly pathological studies and antedated the use of electrocardiography and radiology in diagnosis. The only book written mainly from the clinical standpoint was that of Laubry and Pezzi published as long ago as 1921 .

Brown was the first to give a complete account of the subject, including electrocardiographic and radiological findings, based on a large personal experience, both clinical and pathological, as well as on a comprehensive knowledge of the literature. It was the outstanding work at the time when cardiac surgery began in earnest. Coming from a man engaged in busy general practice, isolated from any University centre, and virtually without clerical or technical assistance, this book may well be regarded as an achievement unparalleled since Mackenzie's Study of the Pulse was published in 1902. No amount of toil and enthusiasm can entirely replace the need for contact and critical discussion with colleagues, and this he achieved by his constant association with Muir at Hull, and by regular visits to London when he often brought specimens with him. Outside cardiological circles, his staunchest friend and counsellor was the late Izod Bennett, Dean of the Middlesex Medical School, who had recognized Brown's genius from the start and did his utmost to foster and encourage it.

After the War, though his reputation as a physician was well established, Brown found himself handicapped by lack of facilities for catheterization and angiocardiography, and by lack of close contact with cardiac surgery, though he became Cardiologist to the Leicester Chest Unit and had some contact with Leeds. Realizing that the methods of Skoda and Rokitansky no longer sufficed for the study of congenital heart disease, he envisaged moving from Grimsby but the practical difficulties of doing so at his age seemed for a time to be insuperable. However, his opportunity came in 1952, when he was appointed to the post of Regional Cardiologist that had been created at Sheffield: indeed his reputation was so high that no other applicant competed with him for the post.

His new appointment provided him with the scientific facilities he needed, without uprooting him entirely from his established base in Lincolnshire which lay within the Sheffield region. Brown saw to it that his new department at the City Hospital had all the necessary laboratory accommoda- 
tion and equipment needed for modern methods of cardiological investigation, and his contacts in the region assured an abundance of clinical material. With the assistance of Whitaker, Heath, and his registrars, the new department was soon in full swing and a series of important papers dealing especially with pulmonary hypertension in congenital heart disease was published.

Much as he accomplished at Sheffield, undoubtedly his most important work was done while he was engaged in busy practice in Lincolnshire. We may well wonder how he found the time and opportunity for such work, and perhaps the answer is supplied in Osler's valedictory address at McGill, when he said that to maintain the student spirit amidst the daily routine of practice needed a strong natural propensity to study, a thirst for knowledge, and an unswerving steadfastness of purpose in its pursuit, an enduring zeal and energy. James Brown possessed all these attributes in full measure.

He was an unconventional character and success changed him not at all. Invariably clad in comfortable tweeds with bow tie, and hands in pockets, his genial and familiar figure never seemed to change over the years. He has been described as a rugged individualist and certainly he did not lack the courage of his convictions or the ability to express them in forthright terms. He judged men as he found them and by his own standards, but anyone who had once gained his confidence and respect could be sure of his support when needed, and he never failed to win the loyalty and affection of his assistants.

To his friends, he was a most lovable man and a delightful companion on all occasions. Skilled in many crafts, a useful artist, a bibliophile, a good judge of wine and food, a connoisseur of old china and pictures, and above all a remarkably shrewd judge of his fellow men, he could talk well on many subjects so that an evening spent in his company was always a rewarding experience. Apart from his work, his main hobby was exploring old furniture and junk shops and he is said to have located and visited every antique shop in the Midlands. He had an eagle eye for anything of interest and his hand had a magnetic attraction for anything of value in a dusty pile of old books. He loved travelling around the country and fortunately his post of Regional Cardiologist permitted him to do so.

All these activities did not prevent him from taking his full share of public duties and he served on the Consultants and Specialists Committee, the Rheumatic Fever and Cardiology Committees of the College of Physicians, the Council of the Cardiac Society, the Editorial Board of the Heart Journal, and the Sheffield Regional Hospital Board.

He accepted his illness in a philosophical way, saying little about it to anyone and continuing his normal work almost up to the time of his death which was mercifully sudden. Months only before his death, Brown married for a second time. By his first marriage he had a son and daughter.

When the history of congenital heart disease comes to be written, Brown will be given a high and honourable place along with Farre, Peacock, Fallot, Théremin, Vierordt, and Maude Abbott, as one whose labours have contributed vitally to the subject.

\section{EVAN BEDFORD}

D. C. MUIR

\section{BIBLIOGRAPHY}

1932. (With D. C. Muir.) Patent Ductus Arteriosus. Arch. Dis. Childh., 7, 291.

1934. (With D. C. Muir.) Patent Interventricular Septum. Arch. Dis. Childh., 9, 27.

1934. Congenital Stenosis of the Aortic Orifice. Lancet, 1, 236.

1934. Coarctation of the Aorta with Infective Endocarditis. Lancet, 2, 924.

1935. (With D. C. Muir) Congenital Heart Disease. Brit. med. J., 1, 966.

1936. Congenital Tricuspid Atresia. Arch. Dis. Childh., 11, 275.

1937. (With D. Evan Bedford.) Congenital Heart Disease. British Encyclopcedia of Medical Practice, 1st edit., Lond.; 2nd edit. 1950.

1939. Congenital Heart Disease. 1st edit., John Bale Medical Publications, London; 2nd edit. 1950. Spanish edit. Translated by R. Kreutzer and J. E. Mosquera, Buenos Aires, 1948.

1943. Interauricular Septal Defect. Bradshaw Lecture, Royal College of Physicians. Not published.

1944. (With F. Hampson.) Temporal Arteritis. Brit. Heart J., 6, 154. 
1950. Congenital Heart Disease. 2nd edit. Staples Press, London.

1954. (With L. M. Gerlis.) A Visual Atlas of Congenital Heart Disease. Harvey \& Blythe, London.

1955. (With D. Heath and W. Whitaker.) Patent Ductus Arteriosus with Pulmonary Hypertension. Brit. Heart J., $17,121$.

1955. (With D. Heath and W. Whitaker.) Eisenmenger's Complex. Brit. Heart J., 17, 272.

1955. (With D. Heath and W. Whitaker.) Cardio-aortic Fistula. Circulation, 12, 819.

1956. (With D. Heath and W. Whitaker.) Muscular Defects of the Ventricular Septum. Brit. Heart J., 18, 1.

1956. (With D. Heath and W. Whitaker.) Ebstein's Disease. Amer. J. Med., 20, 322.

1956. (With D. Heath, W. Whitaker, and T. L. Morris.) Tricuspid Atresia. Brit. Heart J., 18, 499.

1956. (With D. Heath and W. Whitaker.) Total Pulmonary Drainage through a Persistent Left Superior Vena Cava. Brit. J. Clin. Pract., 10, 692.

1956. (With D. Heath and W. Whitaker.) Patent Ductus with Hypertension. Modern Med., 1, 33.

1957. (With D. Heath and W. Whitaker.) Idiopathic Pulmonary Hypertension. Brit. Heart J., 10, 83. 